\title{
PEMBERDAYAAN MASYARAKAT DESA DALAM MELAKSANAKAN REVITALISASI BUDAYA LOKAL “BERSIH DESA” DI KETINGAN, SLEMAN
}

\author{
Sutiyono dan Ni Nyoman Seriati \\ FBS, Universitas Negeri Yogyakarta, \\ email: sutiyono_63@yahoo.com
}

\begin{abstract}
Abstrak: Pemberdayaan Masyarakat Desa dalam Melaksanakan Revitalisasi Budaya Lokal "Bersih Desa" di Ketingan, Sleman. Dalam penelitian ini dikaji tentang pemberdayaan masyarakat dalam mendukung revitalisasi budaya lokal. Tujuan penelitian ini adalah ingin melihat upaya konkrit apa saja yang digunakan untuk memberdayakan masyarakat Desa Ketingan dalam melaksanakan revitalisasi budaya lokal "bersih desa". Penelitian ini dilaksanakan di daerah Ketingan, Sleman, Propinsi Daerah Istimewa Yogyakarta. Waktu penelitian ditentukan selama 8 bulan, yaitu mulai bulan Maret hingga Oktober 2011. Untuk memperoleh data penelitian dilakukan dengan mempergunakan teknik observasi, wawancara, dan dokumentasi. Sebagai pendekatan yang digunakan dalam penelitian ini adalah pendekatan deskriptif. Hasil Penelitian menunjukkan sebagai berikut. Pertama, upaya konkrit untuk memberdayakan masyarakat desa dalam melaksanakan "Bersih Desa" di Ketingan Sleman meliputi: pertama, Rencana Pemberdayaan Masyarakat, identifikasi kelompok-kelompok masyarakat Desa Ketingan yang potensial, identifikas kekayaan lokal, uapaya pemberdayaan masyarakat secara optimal, sosialisasi pemberdayaan; kedua Bersih (1) Acara ritual hadir bakti, (2) Doa bersama, (3) Uraian ritual, (4) Ubo rampe, (5) Acara kirab, (6) Pentas gejok lesung, (7) Pentas wayang kulit, (8) Masakmasak, (9) Gununganuntuk kirab, (10) Biaya, dan yang keempat, Revitalisasi Budaya Lokal, upaya konkrit untuk merevitalisasi budaya lokal dalam melaksanakan "Bersih Desa" di Ketingan Sleman adalah dengan melakukan pembinaan budaya kepada generasi muda dengan label kaderisasi atau regenerasi seniman di desa. Desa, dengan rangkaian acara menjalin jerja saana dengan pihak swasta;
\end{abstract}

Kata kunci: pemberdayaan, revitalisasi, budaya lokal.

\begin{abstract}
The Community Empowerment of Rural in Revitalization The Local Culture "Bersih Desa" in Ketingan, Sleman. In the research studied about empowering the society in supporting the revitalization of the local culture. The purpose of this study is to want to know concrete effots to be empowered the village society of Ketingan, Sleman to do revitalization of localculture "bersih Desa". The research was conducted in the area Ketingan, Sleman, Yogyakarta Province. Study determined the time for 8 months, from Marc to October 2011. To obtain research data had done by using the techniques of observation, interview, and documentation. As the approach used in the study is a qualitative approach. The result show that. First, conceret effort to empower rural communities in implementing the "Bersih Desa" in Ketingan, Sleman consist of: (1) Event ritual devotion present, (2) Prayer together, (3) Description of ritual, (4) Ubo rampe, (5) Carnival event, (6) Performing Gejok Lesung, (7) Performing Wayang Kulit, (8) Cooking, (9) Gunungan for carnival, (10) Cost, and (11) The support society groups. Second, concrete effort to revitalize the local culture implementing "Bersih Desa" in Ketingan, Sleman is to give bulding to the youth with label of regeneration artist in village.
\end{abstract}

Keywords: empowerment, revitalization, local culture. 


\section{PENDAHULUAN}

Ketingan merupakan salah satu desa di Kabupaten Sleman yang telah menyelengarakan program desa wisata. Sebagai unggulan sajian materi wisatanya adalah mengadakan aktivitas budaya masyarakat yang disebut "bersih desa". Bagi masyarakat desa Ketingan, mengadakan acara "bersih desa" bukan hal yang mudah. Hal ini disebabkan sebelum dicanangkan program desa wisata, masyarakat desa ini sudah sejak lama tidak mengadakan acara tersebut. Tetapi masyarakat desa Ketingan tetap yakin bahwa dulunya nenek moyang mengadakan aktivitas budaya "bersih desa". Oleh karena itu, untuk mengangkat kembali aktivitas budaya "bersih desa", masyarakat desa Ketingan mengadakan revitalisasi budaya "bersih desa".

Hal tersebut penting, mengingat selama ini sektor kebudayaan seperti halnya budaya lokal semakin termarginalisasi. Kondisi ini disebabkan oleh beberapa faktor di antaranya proses globalisasi yang didominasi budaya Barat telah masuk ke wilayah pedesaan, dan kenyataannya tidak terdapat resistensi budaya lokal melawan budaya Barat. Di sisi lain budaya lokal dianggap statis dan tidak memadai lagi untuk memenuhi kebutuhan dan ekspresi masyarakat lokal, sementara hadirnya budaya Barat dianggap dinamis dan dianggap lebih sesuai dengan karakter masyarakat sekarang (Thoyibi, 2003).

Kebudayaan adalah warisan nenek moyang yang dimiliki oleh warga masyarakat pendukungnya dengan jalan mempelajarinya. Terdapat suatu mekanisme tertentu untuk mempelajari kebudayaan yang di dalamnya terkandung norma-norma dan nilai-nilai kehidupan yang berlaku dalam tata pergaulan masyarakat pendukungnya, antara lain menjunjung tinggi nilai-nilai penting bagi warga masyarakat demi kelestarian hidup bermasyarakat (Purwadi, 2005: 1). Oleh karena itu suatu masyarakat selalu ingin melakukan revitalisasi terhadap nilai-nilai budaya yang dimiliki, jika nilainilai budaya tersebut terkoyak oleh hadirnya nilai-nilai baru yang dianggap tidak tepat atau merusak tatanan budaya sebelumnya.
Pentingnya revitalisasi budaya lokal disebabkan kehidupan masyarakat yang didasarkan pada kultur masa lampau, kenyataannya lebih baik jika dibandingkan dengan kehidupan masyarakat sekarang yang banyak menyerap budaya luar setiap saat. Memperhatikan hal tersebut, revitalisasi mendesak untuk dilaksanakan. Revitalisasi budaya itu sendiri memiliki banyak pengertian. Kontekstualnya dengan kehidupan sekarang dapat dicari pengertian yang sesuai. Di antaranya, revitalisasi adalah upaya untuk menghidupkan kembali kawasan mati, yang pada masa silam pernah hidup, atau mengendalikan, dan mengembangkan kawasan untuk menemukan kembali potensi yang dimiliki atau pernah dimiliki oleh sebuah kota baik dari segi sosial-kultural, sosio-ekonomi, segi fisik alam lingkungan, sehingga diharapkan dapat memberikan peningkatan kualitas lingkungan kota yang pada akhirnya berdampak pada kualitas hidup dari penghuninya (http:/www.pu.go. id/Ditjenkota-/Revitalisasi/indeks.hti). Dalam hal ini revitalisasi budaya berarti usaha menghidupkan kembali suatu budaya dengan berdasarkan pertimbangan dan tujuan tertentu.

Kita masih perlu melakukan upaya revitalisasi seni dan budaya. Citra luhur seni dan budaya bangsa memerlukan etos kebangsaan, semangat kebersamaan dan kultur keunggulan sebagai bentuk investasi kultural masa depan. Investasi budaya adalah investasi jangka panjang namun tetap efektif dan prospektif karena disegarkan, yang dimekarkan, yang digetarkan adalah totalitas dari pondasi kemanusiaan yang mencakup pikiran kreatifitas kebanggaan dan martabat bangsa yang kita persembahkan bagi kesejahteraan dan perdamaian dunia (SBY, 2006).

Di dalam dunia kepariwisataan sekarang terdapat kecenderungan untuk mengolah potensi daerah, terutama desa beserta strategi pemberdayaan masyarakatnya. Seperti dinyatakan Fandeli, bahwa kebijakan pengembangan pariwisata daerah harus didasarkan pada paradigma yang berkembang di daerah (Fandeli, 2002: 45). Maka logis 
jika ada semacam kehendak untuk menempatkan desa yang berpotensi dan memiliki sumber-sumber produksi sebagai landasan strategisnya, sekaligus memberdayakan masyarakatnya.

Di era reformasi, menempatkan masyarakat desa sebagai subjek pembanguan merupakan hal yang penting. Apalagi sebagian besar wilayah Indonesia adalah wilayah pedesaan dengan jumlah penduduknya yang besar. Oleh karenanya sangat beralasan jika masyarakat desa beserta wilayah pedesaan merupakan topik pembahasan dalam penelitian ini. Pedesaan merupakan wilayah yang sangat potensial, jika dijadikan sebagai wahana aktivitas pembangunan guna meningkatkan kemakmuran masyarakatnya dan memberikan kontribusi terhadap negara. Namun, hingga sekarang kemajuan dan perkembangan wilayah desa belum begitu menggembirakan (Wastutiningsih, 2004: 12). Oleh karena itu menggali potensi desa dan sumber-sember produksi yang selama ini ditelantarkan penting untuk diberdayakan.

Pemberdayaan (empowerment) merupakan proses perubahan pribadi karena masing-masing individu mengambil tindakan atas nama diri mereka sendiri dan kemudian mempertegas kembali pemahamannya terhadap dunia tempat ia tinggal. Pemberdayaan juga merupakan suatu proses yang menyangkut hubungan-hubungan kekuatan (kekuasaan) yang berubah antara individu, kelompok, dan lembaga sosial lainnya (Shragge, 1993). Dalam pandangan Shragge, pemberdayaan ditujukan kepada manusia dalam mengupayakan suatu perubahan untuk memaknai kehidupannya, baik pada tingkat individu maupun kelompok di dalam lingkungan sosialnya.

Jika pemberdayaan menurut Shragge dapat dilakukan pada tingkat individu dan kelompok, tetapi menurut William hanya dilakukan pada tingkat kelompok. Dalam tulisannya tentang "Learning from The Best-from Aesop to Empowerment" (William, 2005: 178), ia berpendapat bahwa pemberdayaan itu dilakukan sebagai usaha kolektif dengan dikerjakan secara bersamasama. Melalui usaha bersama ini, William mengartikan pemberdayaan itu dalam tiga hal, yang satu sama lain saling berkaitan, yaitu: (1) bagaimana membuat pekerjaan dan tujuan organisasi lebih efektif, (2) dalam dimensi lapangan ekonomi yang luas berarti melakukan semua kemungkinan yang dapat mendatangkan rejeki seseorang dan keluarganya dapat melangsungkan kehidupannya, dan (3) dalam dimensi tertentu berarti mengelola dengan pertimbangan misalnya dengan alasan menunjang kehidupan bersama yang harmonis dari pada hanya untuk kepentingan diri sendiri. Dengan demikian pemberdayaan ini dapat dilihat sebagai usaha kelompok untuk mengupayakan suatu pekerjaan lebih efektif, dapat mendatangkan masukan (income) sehingga dapat menunjang kehidupan bersama.

Dalam penelitian ini, terminologi pemberdayaan tersebut dihubungkan dengan masyarakat, sehingga menjadi pemberdayaan masyarakat. Dalam hal ini, masyarakat menempatkan tiga kekuatan sebagai sumber utama pemberdayaan, antara lain: (1). kekuatan sosial, menyangkut akses dasardasar produksi, seperti informasi, pengetahuan, ketrampilan, dan partisipasi dalam suatu organisasi. Kekuatan sosial ini kemudian dapat berubah menjadi kekuatan ekonomi, menyangkut peningkatan aksesakses tersebut terhadap kekuatan produksi. (2) kekuatan politik, menyangkut akses setiap anggota keluarga/masyarakat terhadap proses pembuatan keputusan, terutama yang mempengaruhi masa depan. (3) kekuatan psikologis, menyangkut potensi individu yang menunjuk pada rasa percaya diri (Friedmann, 1992).

Berpijak pada pentingnya pemberdayaan masyarakat desa untuk menghidupkan kembali budaya lokal, maka dalam penelitian ini akan memusatkan pada persoalan pemberdayaan masyarakat desa dalam mendukung revitalisasi budaya lokal yang sekarang ini amat gencar dilaksanakan masyarakat desa di Propinsi Daerah Istimewa Yogyakarta. Dengan harapan revitalisasi budaya 
lokal itu dapat dijadikan sebagai salah satu langkah pelestarian warisan budaya, sebagaimana diwujudkan oleh masyarakat desa Ketingan dalam melakukan revitalisasi budaya "bersih desa" guna menunjang program desa wisata. Hal itu bisa terjadi karena terdapat upaya konkrit untuk memberdayakan masyarakat desa dalam melaksanakan revitalisasi budaya lokal "bersih desa" di Ketingan Sleman. Penelitian ini bertujuan untuk melihat bentuk pemberdayaan masyarakat desa dalam melaksanakan revitalisasi budaya lokal "bersih desa" di Ketingan Sleman. Upaya konkrit apa saja yang ditempuh masyarakat untuk mewujudkan revitalisasi budaya lokal "bersih desa" itu.

\section{METODE}

Penelitian ini bersandarkan pada pendekatan deskriptif. Dengan pendekatan ini, akan dapat menghasilkan data yang valid, reliabel, dan relevan dengan yang didibutuhkan nantinya

Studi ini dilaksanakan di desa Ketingan, salah satu desa yang menyelenggarakan program desa wisata di Kabupaten Sleman. Pemilihan lokus ini dimaksudkan agar dapat menjawab permasalahan penelitian, yakni pemberdayaan masyarakat desa dan revitalisasi budaya lokal "bersih desa" melalui penyelenggaraan program desa wisata. Populasi penelitian ini mencakup masyarakat desa penyelengara program desa wisata, terutama yang telah mengangkat budaya lokal "bersih desa" sebagai suguhan wisata. Adapun sampel penelitiannya adalah para anggota masyarakat yang tergabung dalam kelompok organisasi pengelola desa wisata, antara lain kelompok kirab, jathilan, korps drum band, among tani, kandang sapi, gejok lesung, pemuda, dasa wisma., dan ibu PKK. Pengambilan sampel didasarkan pada teknik purposive sampling, yakni dengan cara mengambil subjek, yang bukan didasarkan atas strata, random, lokasi, akan tetapi didasarkan atas tujuan tertentu.

Teknik pengumpulan data dilakukan dengan observasi ke lapangan, wawancara, dan dokumentasi. Data penelitian dianalisis dengan teknik deskriptif interpretatif, yaitu pelukisan situasi yang diperoleh dan kemudian dianalisis dalam bentuk kata-kata untuk menghasilkan suatu makna dan kesimpulan. Proses analisis ini dilakukan dengan mempergunakan model analisis deskriptif.

\section{HASIL DAN PEMBAHASAN}

Dusun Ketingan merupakan desa yang kecil yang termasuk wilayah kota Kecamatan Mlati Kabupaten Sleman, Propinsi Daerah Istimewa Yogyakarta. Desa ini merupakan salah satu desa percontohan dalam wilayah Kelurahan Tirtoadi, Kecamatan Mlati telah diprogramkan pemerintah kabupaten sebagai desa wisata dengan kemampuan pesona alam sekitar dan potensi budaya lokal.

Dalam tingkat ekonomi, penduduk Dusun Ketingan sebagian besar penghasilan dari pertanian, kerja proyek, wiraswasta, dan sebagian kecil pegawai negeri. Di dusun ini sudah terbentuk beberapa organisasi atau perkumpulan yang berjalan baik. Semuanya ini diadakan rutin sehingga setiap organisasi ini berjalan sesuai dengan bentuk tujuan organisasi. Organisasi-organisasi itu antara lain kelompok jathilan, korps drum band, among tani, kandang sapi, gejok lesung, pemuda, dasa wisma, dan ibu PKK.

Organisasi-organisasi itu yang secara konkrit membentuk panitia untuk mengupayakan terbentuknya pemberdayaan masyarakat untuk mewujudkan revitalisasi budaya lokal "bersih desa" tersebut. Upaya-upaya konkrit yang telah ditempuh meliputi rencana pemberdayaan masyarakat sampai dengan pelaksanaan pemberdayaan acara bersih desa, dan revitalisasi itu sendiri.

\section{Rencana Pemberdayaan Masyarakat}

Upaya konkrit yang digunakan untuk memberdayakan masyarakat Desa Ketingan dalam melaksanakan revitalisasi budaya lokal "bersih desa" ditempuh dalam bentuk rencana pemberdayaan masyarakat meliputi:

a. Mengidentifikasi kelompok-kelompok masyarakat di Desa Ketingan yang ber- 
potensi untuk diberdayakan, guna mendukung pelaksanaan budaya lokal "bersih desa";

b. Mengidentifikasi kekayaan lokal atau budaya lokal yang telah dimiliki Desa Ketingan;

c. Upaya pemberdayaan masyarakat ini harus melibatkan seluruh potensi masyarakat Desa Ketingan dan masyarakat di luar Desa Ketingan yang mendukung jalannya aktivitas Bersih Desa;

d. Sosialisasi tentang rencana pemberdayaan masyarakat dengan melibatkan seluruh potensi masyarakat;

e. Menjalin kerja sama dengan pemerintah dan pihak swasta dalam melaksanakan pemberdayaan masyarakat guna menyukseskan aktivitas Bersih Desa.

Rencana pemberdayaan masyarakat desa ini menjadi sangat penting mengingat Ketingan merupakan salah satu desa wisata terbaik di Propinsi DIY yang mampu mengangkat budaya lokal, sehingga dalam hal ini layak dijadikan sebagai model pemberdayaan masyarakat desa. Melalui model ini diharapkan oleh pemerintah dapat ditiru oleh desa-desa lain yang sekarang ini sedang dalam pembenihan menjadi desa wisata.

Pada tanggal 12 Desember 2006 telah diadakan sosialisasi yang dihadiri seluruh warga Ketingan dengan keputusan telah disepakati untuk diadakan Merti Dusun (Bersih Desa) sekaligus pembentukan panitia. Setelah terbentuk panitia penyelenggara Merti Dusun pada tanggal 22 Desember 2006 diadakan pertemuan panitia yang pertama untuk pemantapan personil dan pemberian tugas masing-masing personil. Dalam pertemuan ini telah ditetapkan panitia yang melibatkan 68 orang warga Desa Ketingan. Dari ke-68 orang tersebut masing- masing mempunyai tugas (job description) yang ditetapkan atas kesepakatan bersama, mulai dari Penasehat, Pelindung, Penanggung Jawab, Ketua Panitia, Sekretaris, Bendahara, Pembantu, Seksi Pencari Dana, Seksi Perlengkapan, Seksi Kepemudaan, Kesenian, Komunikasi, Dokumentasi, Keamanan, Konsumsi, hingga Humas.

\section{Bersih Desa}

Upaya konkrit yang telah terlaksana untuk memberdayakan masyarakat Desa Ketingan dalam melaksanakan revitalisasi budaya lokal "bersih desa" meliputi:

\section{Hadir Bakti}

Acara ritual hadir bhakti diawali dengan upacara serah terima, berupa ubo rampe ritual. Dalam upacara ini masyarakat menyajikan ubo rampe dikumpulkan menjadi satu untuk diserahkan kepada Kepala Dusun. Kepala Dusun menyerahkan ke pimpinan ritual untuk disajikan dalam acara Ritual Hadir Bhakti. Setelah penyerahan uba rampe, diadakan doa bersama. Dalam doa bersama ini, masyarakat Dusun Ketingan berkumpul bersama untuk berdoa yang dipimpin oleh pimpinan ritual, yaitu memohon dan bersyukur bahwasanya masyarakat telah diberi keselamatan rejeki dari bumi Ibu Pertiwi Desa Ketingan.

Uraian ritual ini diberikan oleh Pimpinan Ritual memberikan penjelasan menganai $u b a$ rampe kepada masyarakat Dusun Ketingan. Di samping itu, pimpinan ritual juga memberikan kesempatan kepada masyarakat yang belum mengerti arti dan maknanya ritual untuk bertanya kepada pimpinan ritual. Ubo rampe ritual Hadir Bhakti terdiri dari pisang raja 1 sisir utuh, pisang ambon 1 sisir utuh, pisang emas 1 sisir utuh, ayam panggang (jago kemanggang) 1 ekor utuh, ayam kemanggang mentah untuk di kubur 1 ekor utuh, kain moro 1 meter, nasi putih (di taburi bawang merah), nasi kuning, osengoseng, sambal goring, ikan emas goreng dan sambal trasi, ikan emas di bakar \& bumbu santan, buah-buahan, semangka 1 buah, dan nanas.

Untuk melengkapi uba rampe tersebut, juga disajikan minuman meja terdiri dari teh 1 bungkus, kopi 1 bungkus, susu putih bendera 1 kaleng, selasih, telur ayam kampung \& garam \& brambang, cabai merah utuh terasi bakar, tantang angin, rokok Dji Sam soe 1 bungkus, Gudang garam merah 1 bungkus, Gudang garam hijau 1 bungkus, Djeruk filter 1 bungkus, Ardath Merah Putih 1 bungkus. Rokok klobot 1 bungkus, Rokok 
djolali 1 bungkus, Cerutu 1 kotak isi 5 biji, Sirup ABC Cocopandan \& sirsat, kelapa muda 2 buah, Tumpeng 7 warna, Tumpeng gugur gunung, Gula batu Merah \& putih setengah kilo, Minyak misik, Hadir kapuk (hasil alam), nasi putih dikepal 3 biji, rendang daging/telur ayam kampung 3 biji, Cerutu, Jeruk mandarin, Kelapa muda 1 buah, Bunga Tabur Merah Putih utuh 3 pasang, Dupa 3 biji, Wijikan Daun pisang, Tampah, Wijikan \& lap, bersih, kerupuk.

\section{Pentas Gejug Lesung}

Pentas gejug lesung sudah ada sebelum tahun 1960, tetapi kesenian ini tidak di budidayakan, dan sekarang diuri-uri lagi karena Dusun Ketingan di tunjuk sebagai desa wisata, dan untuk menyajikan (menyuguhkan) kepada tamu yang dating ke Dusun wisata Ketingan. Lesung yang di pakai dibeli dari Gunung Kidul dan memilih kayu jati. Dalam pentas Gejug Lesung ini yang ikut warga Desa Ketingan sendiri dan di latih oleh $\mathrm{Bu}$ Haryati dan dalam latihan bertempat di kepala Dukuh desa Ketingan Sendiri. Lagu yang di gunakan dalam Gejug Lesung ini biasanya menggunakan lagu Dolanan. Sebelum pentas dilaksanakan latihan beberapa hari sebelum hari $\mathrm{H}$, dan dalam pentas menggunakan baju lurik dan jarit untuk ibu-ibu.

\section{Kirab}

Menyiapkan ubo rampe kirap, terdiri dari: Tumpeng/Gunungandari nasi serta perlengkapannya, Gununganhasil pertanian atau buah-buahan dan sayur-sayuran, Air tuk tujuh yang sudah disiapkan 6 sumber yang satu sumber diambil secara simbolis di tuk sewudel bersamaan dengan kirap, Pasukan prajurit, Dewi Sri, kelompok kuntul, Spanduk, Jatilan, Drum band, dan Bungabunga untuk tabor bunga

Kirab bisa di adakan kirab karena dusun ketingan merupakan salah satu dusun yang di tunjuk sebagai desa wisata dan ada penggalian dari tokoh masyarakat untuk mengadakan kirab sebagai rasa syukur terhadap Tuhan Yang Maha Esa. Barisan bergodo dalam kirab ini sangat banyak dan tiap krlompok mempunyai nama yang berbeda-beda yaitu Kelompok berkuda; Dewi Sri; tokoh masyarakat; tokoh Agama; Pusaka; Gunungan hasil bumi; Kelompok RT dan terdiri dari 4 RT; Kuntul (Bangau); Drum band; Andong; Perangkat Desa; Gunungan; semua masyarakat dari anak, ibu-ibu, sampai yang sudah lanjut usia, akan tetapi yang sudah lanjut usia masyarakat ketingan menyediakan kereta kelinci; dan yang terakhir jathilan. Dalam acara kirab ini yang merias yaitu warga masyarakat Ketingan sendiri, kecuali bagi yang berperan sebagai Dewi Sri di rias oleh perias, karena riasan yang di pakai lebih sulit. Sebelum pelaksanaan kirab di adakan latihan beberapa hari sebelum acara diselenggarakan.

Acara kirab sendiri di mulai dari jam 13.00 WIB untuk persiapan, dan jam 14.00 WIB berangkat. Rute perjalanan Kirab dimulai dari (1) Star dari rumah Kepala Dusun Ketingan, (2) Menuju kantor KelurahanTirtoadi, (3) Menuju kantor Kecamatan Mlati, (4) Muter barat cebongan, dan (5) terakhir kembali menuju ke rumah Kepala Dusun Ketingan.

Semua Gunungan yang terdiri dari 3 jodag yaitu Gunungan hasil bumi (palawija), Tumpeng besar, dan buah-buahan diperebutkan oleh warga masyarakat Ketingan dan sekitarnya. Konsumsi dalam kirab ini disediakan makanan berupa nasi dus dan Snak. Acara kirab sampai tahun ini diadakan karena sudah merupakan suatu tradisi, naluri masyarakat. Percaya atau tidak percaya dengan adanya acara merti bumi ini merupakan suatu ucap syukur terhadap Tuhan Yang Maha Esa. Kirab yang ada di dusun Ketingan ini bertujuan untuk yang pertama sebagai ucap syukur kepada Tuhan Yang Maha Esa, agar panen pada tahun berikutnya lebih melimpah dari pada tahun sebelumnya. kedua: dari masyarakat kepada pemerintah bahwa masyarakat dusun ketingan menunjukkan rasa berbakti kepada pemerintah dengan adanya kirab.

\section{Pentas Wayang Kulit}

Pentas wayang kulit merupakan acara puncak kegiatan Bersih Desa. Dalam acara Wayang kulit Dalang yang didatangkan dari 
Kulon Progo yaitu Bambang Wiji, tetapi pada tahun 2007 acara wayang dengan dalang Ki Wondo. Pentas wayang kulit tersebut pada malam hari, dan satu malam penuh (semalaman). Gamelan dan wayang yang digunakan untuk pentas menggunkan gamelan dan wayang dari dalang tersebut (seperangkat). Dalam acara wayang tersebut penonton tidak hanya dari dusun Ketingan tetapi terbuka untuk umum. Pada tahun kemarin (2011), lakonnya yaitu PETRUK DADI RATU, dan yang menentukan lakonnya adalah warga masyarakat sendiri. Biaya yang digunakan untuk acara wayang sendiri mencapai 30 juta. Dana tersebut di peroleh dari warga masyrakat, setiap KK di tarik dengan uang minimal Rp. 50.000,- (kurang mampu) tetapi jika yang mampu lebih dari Rp. 50.000,- dan dari sponsor. Pementasan puncak acara diadakan wayangan baru $2 \mathrm{x}$, sedangkan tahun sebelumnya mementaskan Ketoprak dan pemainnya warga masyarakat dusun ketingan sendiri.

\section{Pendukung Pelaksanaan Bersih Desa}

\section{Konsumsi Bersih Desa}

Khususnya kegiatan masak untuk konsumsi Bersih Desa ini melebihi orang punya kerja. Hal ini diperlihatkan masyarakat Desa Ketingan Ketingan yang menghabiskan waktu 10 hari untuk menyiapkan konsumsi Bersih Desa, mulai dari persiapan sampai hari terakhir (selesai). Jumlah konsumsi dipertimbangkan berdasarkan warga desa yang ikut kirab mencapai kurang lebih 527 orang, dan masih ditambah jumlah anak-anak yang terlibat. Dalam kirab ini bagian konsumsi tidak hanya memberi makan pada warga masyarakat Ketingan saja, tetapi juga memberi konsumsi kepada kelompok Bergodo dari desa lain yang diundang untuk memeriahkan acara kirab Bersih Desa, yaitu bergodo dari "Mbah Bergas” (Ngino), Gamping, dan Cebongan. Tetapi semua itu mengukur kemampuan besarnya dana dari warga masyarakat Desa Ketingan sendiri khususnya ibu-ibu yang ikut masak-memasak, karena yang ikut masak-memasak juga ikut kirab juga.
Dana untuk konsumsi Bersih Desa mencapai Rp. 25.000.000,-. Tenaga untuk mempersiapkan konsumsi dengan jumlah besar ini adalah dengan cara memberdayakan warga Desa Ketingan sendiri. Mulai dari anak kecil sampai ibu-ibu yang sudah tua mereka ikut berpartisipasi masak-memasak. Tempat untuk masak adalah rumah Bu Dukuh. Peralatan yang dipakai yaitu peralatan yang sudah tersedia di setiap RT, karena setiap RT mempunyai inventaris barang-barang untuk keperluan masak yang saling melengkapi antara RT yang satu dengan yang lainnya. Semua masakan akan dihidangkan untuk sejumlah 850 orang untuk tahun sekarang. Pada tahun kemarin mencapai 1000 orang karena mengundang tiga bergodo yaitu dari Ngino, Cebongan, Gamping, dan kebetulan tahun kemarin kedatangan Ngarso Dalem Kanjeng Ratu Hemas.

\section{Gunungan untuk kirab}

Bahan yang digunakan untuk Gunungan yaitu hasil bumi Desa Ketingan, yaitu palawija, sayur-sayuran, buah-buahan, dan yang digunakan untuk slemek (alas) berupa tampah besar. Jumlah Gunungan untuk kirab ada 3 jodang yaitu, Gunungan tumpeng besar yang berisi ingkung (ayam yang sudah dimasak tetapi utuh) beserta gudangan. Gunungan hasil pertanian (sayur-sayuran), Gunungan (buah-buahan), dan Gunungan tersebut dibuat menyerupai Gunungan dari Keraton Yogyakarta. Setiap Gunungan mempunyai nama yaitu Gunungan palawijo, Gunungan Hadir Bakti (Bulu Bhekti) dan Gunungan Panganan. Ketiga Gunungan tersebut di buat oleh warga masyarakat dusun Ketingan sendiri. Dalam membuat ketiga Gunungan tersebut menghabiskan uang sebesar Rp. 2.000.000,-.

Gunungan-Gunungan tersebut mempunyai arti. Yang pertama Gunungan hasil bumi (palawijo) berarti agar hasil bumi tersebut bersih. Dan yang kedua padi sendiri hanyalah padi yang sudah ditentukan yaitu padi Raja Lele dan untuk memetiknya harus memakai alat khusus yaitu ani-ani. Makna dari Gunungan tersebutyaitu:(1) Agar hasil panen 
tahun berikutnya lebih melimpah, (2) Untuk mengucapkan terimakasih kepada pemerintah, semoga pemerintah bisa mendukung semua rakyat dan juga bisa menjalankan amanah sesuai dengan peraturan yang ada, dan (3) Masyarakat yang memperebutkan Gunungan tersebut supaya mendapat berkah. Setelah selesai kirab, Gunungan diperebutkan oleh masyarakat. Terdapat kepercayaan, jika dapat memperebutkan Gunungan dan air dari tujuh sumber tersebut akan mendapatkan rezeki.

\section{Aliran Bantuan}

Acara yang di selenggarakan setiap setahun sekali ini mempunyai manfaat yaitu dalam istilah jika orang bersedekah maka akan mendapatkan rezeki yang berlipat. Istilah itu terermin dalam sedekah (urunan) yang diberikan oleh warga masyarakat Desa Ketingan dalam acara Bersih Desa. Rezeki yang berlipat itu berupa bantuan dari provinsi dan kabupaten yang tidak kecil yang diberikan kepada masyarakat Desa Ketingan. Contohnya: pengaspalan yang ada di tengah Desa Ketingan dan selatan desa mendapat bantuan sebesar 60 juta. Bantuan juga diberikan kepada kelompok Kandang sebesar 350 juta, gamelan 70 juta, kelompok masjid 5 juta, kelompok warung kecil 20 juta. Bahkan yang berhubungan dengan pengairan yaitu bantuan sumur bur sebesar satu milyar rupiah.

Demikian pula setiap masyarakat Desa Ketingan mengadakan acara Bersih Desa dengan biaya swadana dari masyarakat, ternyata dalam kenyataannya juga mendapat bantuan dari pemerintah desa, Kecamatan, Kabupaten, Provinsi, Pertamina (untuk tahun kemarin 2011), Dinas pariwisata kabupaten dan provinsi, UD Sregep, pengadaian, serta dari pihak sponsor. Bantuan dari berbagai pihak itulah yang menjadikan kegiatan Bersih Desa dapat terlaksana secara rutin.

\section{Revitalisasi Budaya Lokal}

Dengan maksud melakukan revitalisasi budaya lokal, tampak kegiatan tradisi Bersih Desa hidup kembali melalui pemberdayaan masyarakat Desa Ketingan. Mengenai man- fatnya yaitu bahwa yang direvitalisasi tidak hanya bentuk budaya lokal saja, misalnya seni kuda lumping yang dulunya dipresentasikan dalam satu malam, kemudian direvitalisasi menjadi dua jam saja. Selain itu yang direvitalisasi yaitu para senimannya. Para seniman yang telah berusia lanjut diganti oleh para seniman muda. Para remaja berumur antara 9 hingga 20 tahun disuruh untuk mengadakan latihan seni kuda lumping. Ajang ini merupakan kesempatan generasi muda untuk mengembangkan diri menjadi seniman kuda lumping. Apa yang diupayakan generasi muda ini dapat dibuktikan hasilnya pada acara kegiatan Bersih Desa. Mereka menampilkan satu paket seni kuda lumping sebagai hasil (product) penafsiran dan pengembangan diri selama berbulan-bulan. Hal ini berarti bahwa revitalisasi budaya lokal juga ditempuh melalui kaderisasi atau regenerasi seniman, yang ujung-ujungnya adalah pelestarian budaya lokal itu sendiri.

Cara masyarakat Desa Ketingan untuk melakukan regenerasi kesenian, seperti seni kuda lumping ditempuh dengan mengadakan pembinan budaya. Masyarakat memandang, bahwa para generasi muda yang selama ini menjadi pecinta seni kuda lumping hanya menjadi penonton saja. Jika terdapat pertunjukan seni kuda lumping baik yang terjadi di desanya sendiri maupun di luar desa, mereka berusaha untuk dapat menonton dan menikmati kesenian tersebut. Pendek kata, mereka hanya sebagai penonton saja. Seharusnya mereka berpikir, apakah bisa melakukan seperti para seniman kuda lumping itu. Atas dasar persepsi bersama masyarakat Desa Ketingan, para generasi muda itu dikumpulkan dan dibina bersama untuk berlatih seni kuda lumping. Ternyata mereka bisa melakukan. Dalam waktu tiga bulan, mereka sudah trampil menarikan seni kuda lumping. Langkah selanjutnya adalah mereka diwadahi dalam kelompok bersama. Di sinilah, cara masyarakat Desa Ketingan dapat dijadikan sebagai wahana terbentuknya kelompok kesenian kuda lumping. Hal ini pula berlaku untuk membina seni 
tradisi dan budaya lokal yang lain, yang sekarang nasibnya memprihatinkan.

Dalam hubungan ini, kegiatan tradisi Bersih Desa dapat dianggap sebagai wadah untuk mengintegrasikan seluruh komponen masyarakat di Desa Ketingan. Wadah ini juga mencerminkan bahwa Bersih Desa merupakan media silaturahmi antar tetangga sebagai warga desa yang memiliki kepentingan bersama. Dalam satu desa tentu saja terdiri dari beraneka ragam perbedaan seperti perbedaan agama atau keyakinan, pikiran, kepentingan yang dimiliki setiap warga. Tetapi melalui aktivitas bersih desa, keterlibatan warga desa yang jumlahnya hampir seluruh desa dianggap telah menyatakan satu nusa, satu bangsa, dan satu bahasa. Sebagai contoh, mereka berjalan bersama dalam satu kirab, mengadakan kerjabakti untuk membersihkan kampung, masak bersama, menonton wayang kulit bersama, dan masih banyak kegiatan lain yang harus dilakukan secara bersama-sama. Mereka tampak bekerja dengan bergotongroyong, bau-membau, menyatukan persepsi untuk tujuan bersama. Dengan demikian, kegiatan Bersih Desa dapat dinyatakan sebagai forum rekonsialisasi sekaligus integrasi masyarakat desa.

\section{SIMPULAN}

Upaya konkrit yang digunakan untuk memberdayakan masyarakat Desa Ketingan dalam melaksanakan revitalisasi budaya lokal "bersih desa" ditempuh dalam bentuk rencana pemberdayaan masyarakat. Rencana tersebut meliputi: mengidentifikasi kelompok-kelompok masyarakat, mengidentifikasi budaya lokal, upaya pemberdayaan masyarakat dengan melibatkan seluruh potensi masyarakat, sosialisasi tentang rencana pemberdayaan masyarakat, dan menjalin kerja sama dengan pemerintah dan pihak swasta.

Upaya konkrit itu telah dilaksanakan untuk memberdayakan masyarakat Desa Ketingan dalam melaksanakan revitalisasi budaya lokal "bersih desa" yang terwujud dalam acara-acara sepert: Hadir Bakti, Pentas Gejug Lesung, Kirab, dan Pentas Wayang Kulit. Adapun sebagai pendukung pelaksanaan Bersih Desa antara lain berupa Konsumsi Bersih Desa, Gunungan untuk Kirab, dan Aliran Bantuan. Dengan maksud melakukan revitalisasi budaya lokal, tampak kegiatan tradisi Bersih Desa yang ditempuh melalui pemberdayaan masyarakat ini menghidupkan kembali budaya lokal, seperti makanan tradisional, gejok lesung, kuda lumping, dan wayang kulit. Rasa sosial yang diwujudkan melalui gotong royong, urunan dana, dan kebersamaan untuk membuat gunungan, masak (konsumsi), kebersihan kampung ini membuktikan upaya pemberdayaan masyarakat benar-benar dapat dirasakan oleh seluruh masyarakat Desa Ketingan.

\section{DAFTAR PUSTAKA}

Fandeli, Chafid. 2002. Perencanaan Kepariwisataan Alam. Yogyakarta: Fakultas Kehutanan, Universitas Gadjah Mada.

Friedmann, John. 1992. Empowerment: The Politics of Alternative Development. Cambridge Mass: Blackwell Publisher.

Purwadi. 2005. Upacara Tradisional Jawa: Menggali Untaian Kearifan Lokal. Yogyakarta: Pustaka Pelajar.

Shragge, Eric. 1993. Community Economics Development, In Search of Empowerment and Alternative. London:Black Rose Books.

Thoyibi, M (et. al.). (ed.). 2003. Sinergi Agama dan Budaya Lokal: Dialektika Muhammadiyah dan Seni Lokal. Surakarta: UMS Press.

Wastutiningsih, Sri Peni. 2004. "Pemberdayaan Petani dan Kemandirian Desa”, Dinamika Pedesaan dan Kawasan, Vol 4, No. 4, p. 12-18.

William I, Gorden. 2005. "Learning from The Best-from Aesop to Empowerment". Vital Speeches of the Day, Vol 7, Jan, p. 178.

Yudoyono, Susilo Bambang. 2006. "Sambutan Peresmian Pembukaan Pesta Kesenian Bali ke-28". http://www.presidenri. go.id/index.php/pidato/17/06/2006. 